\title{
An efficient method to assess erosion risks in tidal basins
}

\author{
D.W. Dusseljee, A.L. de Jongste and M.H.P. Jansen ${ }^{1}$ \\ ${ }^{1}$ Witteveen+Bos B.V., P.O. box 2397, 3000 CJ Rotterdam, The Netherlands, d.dusseljee@,witteveenbos.nl
}

\begin{abstract}
Predicting erosion of channel banks and tidal flats due to wind waves in tidal basins involves multiple parameters. These parameters represent the hydrodynamic load onto a bank as well as the stability of a bank against erosion. An efficient method to predict bank erosion in tidal basins is by calculating the sediment stability parameter based on the initiation of motion of sediment particles, because this parameter includes both the oscillatory bed stress and the sediment characteristics. The loading by wind waves on banks and tidal flats can be quantified by the bed shear stress. Wave breaking can be quantified by means of the intensity parameter of energy dissipation by wave breaking. Calculation of the sediment stability parameter gives insight in the locations where erosion or sedimentation may occur in the future.

As a case study, the future reintroduction of the tide in Lake Grevelingen, in the Netherlands, is studied. The reintroduction of the tide may be combined with a tidal power plant in the Brouwersdam, between the North Sea and Lake Grevelingen. Reintroduction of the tide will change the wave load on intertidal areas in Lake Grevelingen. The effects of a tidal power plant in the Brouwersdam on erosion and the effectiveness of bank protection in Lake Grevelingen are analysed. The results of this morphological analysis are used as input for an environmental impact assessment. This case study shows that studying the initiation of motion is an efficient method to assess the local risks of (bank) erosion.
\end{abstract}

\section{INTRODUCTION}

\section{Erosion of channel banks and tidal flats}

Intertidal areas are often highly valuable and unique ecosystems. Erosion of the channel banks and tidal flats can be a serious threat to these areas. It is therefore important to understand and predict bank erosion of intertidal areas in tidal basins.

Methods available to examine bank erosion and the risks of bank erosion comprise measurement campaigns, physical scale modelling and/or numerical morphological modelling.

Bank erosion may be diagnosed by measurement campaigns. Many measurement techniques are available [Thorne, 1981]. In particular, remote sensing techniques have proven themselves very useful for measuring bank erosion [Thoma et al., 2005]. Measuring changes - however valuable these measurements are can only be done afterwards, and can most often not be used to predict the impact of a change on the system.

Another method to study erosion is through physical scale modelling. Physical scale modelling of bank erosion is appropriate to gain knowledge about natural processes under hypothetical situations. For meandering rivers, this has been carried by Utrecht University [Kleinhans et al, 2010]. However, physical scale modelling may easily suffer from scale effects, particularly in morphological scale modelling.

Morphological modelling of bank erosion is possible with numerical models, like Delft3D [Deltares, 2011]. At the moment, the standard numerical scheme of Delft3D for erosion does not allow erosion of the dry parts of banks. However, an optional scheme is implemented which can redistribute the erosion flux of wet cells over the adjacent dry cells.

\section{Case study Lake Grevelingen}

Bank erosion risks are also an issue in the policy analysis for Lake Grevelingen (MIRT Verkenning Grevelingen). Lake
Grevelingen is the largest salt-water lake in Western Europe. This lake is a former estuary in the south-western part of the Netherlands which has been closed after the flood of 1953 by the construction of the Brouwersdam in 1971. Because of this closure, the tidal flow in the Grevelingen disappeared and the development of intertidal flats was hampered [Deltares, 2010; Rijkswaterstaat Zeeland, 2010]. However, the eroding forces of local wind waves persist. In absence of tidal water level variations, these forces now act on bank slopes at a constant level. As a consequence, the edges of tidal flats and banks have been eroded considerably (Figure 2). Therefore, many edges of tidal flats are now protected by bank protection and foreshore dams (Figure 1).

In a recent policy analysis on the future development of Lake Grevelingen, the possibilities to (partially) reintroduce the tide in Lake Grevelingen are studied. The reintroduction of the tide may be combined with a tidal power plant in the Brouwersdam, between the North Sea and Lake Grevelingen. The construction of a conduit in the Grevelingendam, the reconstruction of the Flakkeese flushing sluice and the construction of a navigation lock

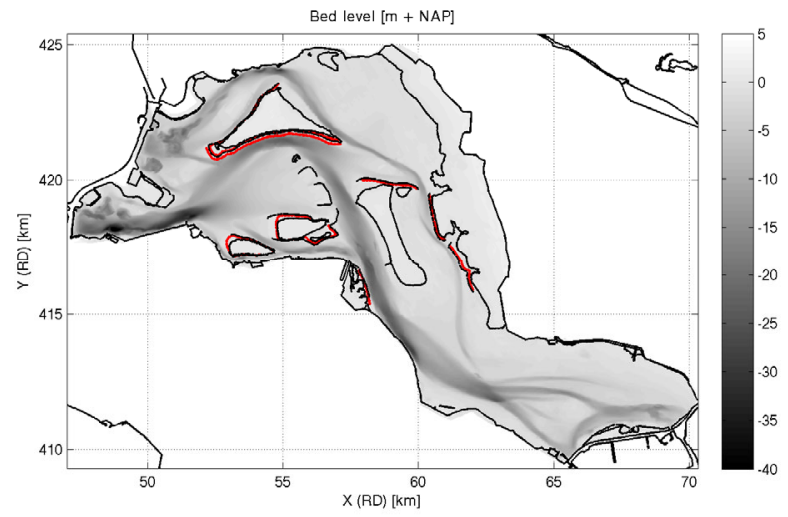

Figure 1. Bed level of Lake Grevelingen with the main protected banks (in red). 


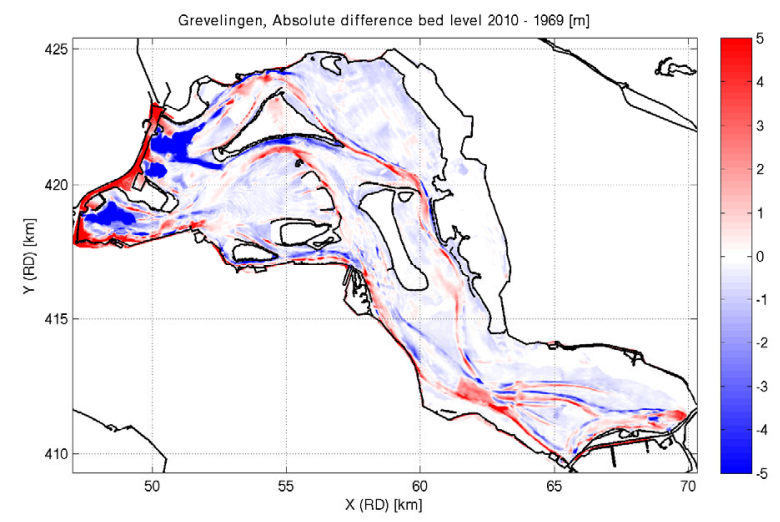

Figure 2. Bed level difference between 2010 and 1969 [m].

have also been considered [Witteveen + Bos, 2011].

It is important to determine the effects of reintroduction of the tide on the morphology of Lake Grevelingen and on the outer delta of Grevelingen estuary. Witteveen+Bos and Deltares have studied the morphological effects on sandbanks and channels in the outer delta and also on dispersion of mud and erosion of intertidal areas in Lake Grevelingen.

The effects of reintroducing the tide on erosion and the effectiveness of bank protection are analysed based on wave modelling and several morphological parameters in Lake Grevelingen. This purpose of this study is to describe this method to assess erosion risks in tidal basins. The results of this analysis are used as input for an environmental impact assessment [Witteveen + Bos, 2011].

\section{METHODOLOGY}

\section{Morphology}

Three morphological parameters are considered to determine the effect of waves on sedimentation and erosion patterns. These parameters indicate where erosion or sedimentation will change in the future:

1. the significant bed shear stress due to waves;

2. an intensity parameter of energy dissipation due to wave breaking;

3. an initial sediment stability parameter for waves.

Sediment can be stirred up and transported when near-bed velocities, caused by the oscillatory motion of waves, exceed the critical velocity for initiation of motion. The bed shear stress and the sediment stability parameter are directly derived from these near-bed velocities.

\section{Significant bed shear stress}

Here, the significant bed shear stress due to waves is the amplitude of the bed shear stress due to the orbital velocity amplitude directly above the boundary layer near the bed. These shear stress coefficients represent the influences of waves on the bed, with a shear stress increase occurring when water depths decreases or when the wave height increases. In deep water, the shear stress is very small since the orbital motion does not reach the bed. The significant shear stress (in $\left[\mathrm{N} / \mathrm{m}^{2}\right]$ ) is defined as:

$$
\tau_{w}=\frac{1}{2} \rho f_{w} u_{b}^{2}
$$

In this formula, $\rho$ is the density of water and $f_{w}$ is the friction coefficient corresponding to an orbital velocity $u_{b}$. The maxima of the orbital velocity are equal to $u_{b}=\sqrt{2} \cdot U_{r m s}$. $U_{r m s}$ is the rootmean-square value of the orbital velocity near the bed just outside the boundary layer [Schiereck and Fontijn, 1996]. The friction coefficient $f_{w}$ may be determined by:

$$
\begin{gathered}
f_{w}=0.00251 \exp \left[5.21 \cdot\left(\frac{A}{k_{s}}\right)^{-0.19}\right] \text { for } \frac{A}{k_{s}}>1.57 \\
f_{w}=0.3 \quad \text { for } \frac{A}{k_{s}} \leq 1.57
\end{gathered}
$$

In these formulas, $k_{s}$ is the Nikuradse roughness height. And $A$ is the horizontal amplitude of the bed oscillation and according to:

$$
A=\frac{u_{b} \cdot T_{m ; b e d}}{2 \pi}
$$

In this formula, $T_{m \text {;bed }}$ is the mean wave period at the bed [Soulsby et al., 1993].

\section{Wave breaking parameter}

The intensity parameter of energy dissipation due to wave breaking (in $\left[\mathrm{m}^{2} / \mathrm{s}\right]$ ) shows where wave breaking and related wave energy dissipation will occur. This wave energy loss can produce a lot of turbulence which can stir up sediment. And the wave breaking induces a mean current through the associated radiationstress gradients. This is why sediment transport is relatively high in the breaking zone.

The dissipation of energy due to wave breaking is defined as energy dissipation per unit of time due to wave breaking caused by decreasing water depth [Delft University of Technology, 2011].

\section{Initial sediment stability parameter}

The initial stability parameter shows where the bed material will be disturbed and sediment can move. Initiation of motion of sediment is defined as a dimensionless parameter $S$ :

$$
S=\frac{d_{50}}{d_{c ; n 50}}-1
$$

In this formula, $d_{50}$ is the local median grain size of the bed (assumed to be $180 \mu \mathrm{m}$ in Lake Grevelingen, based on [Nieuwenhuize et al., 1995]) and $d_{c ; n 50}$ is the critical grain size diameter based on [Schiereck and Fontijn, 1996]:

$$
d_{c ; n 50}=2.15 \frac{\hat{u}_{b}^{2.5}}{\sqrt{T_{m ; b e d}(\Delta g)^{1.5}}}
$$


In this formula, $\hat{u}_{b}$ is the maximum orbital velocity near the bed and $T_{m \text {;bed }}$ is the mean wave period near the bed. Negative values of $S$ mean that sediment may be stirred up under the influence bed orbital velocities. Positive values of $S$ indicate that the orbital velocities are relatively small and no initiation of motion will take place. This method is comparable with the theory of Shields for uniform flow [Shields, 1936].

\section{Numerical wave modelling with SWAN}

\section{Wave model set-up}

The numerical spectral wave model SWAN [Delft University of Technology, 2011] is used to determine wave conditions in the tidal basin. SWAN is specially developed for application in environments with shallow water and reproduces wave processes like wind growth of the waves, depth-induced wave breaking and 'whitecapping', 'shoaling', refraction, wave transmission and wave reflection. SWAN is used to provide the relevant wave parameters needed to get insight in the (bank) erosion processes.

For the case Lake Grevelingen, a rectangular grid has been made with a resolution of $20 \mathrm{~m}$ (1225 by 805 grid points). The grid size is small enough to calculate the relevant processes near steep banks [Van Vledder et al., 2008] and to include bank protections and foreshore defences.

Bathymetric records of Rijkswaterstaat are used for the wave

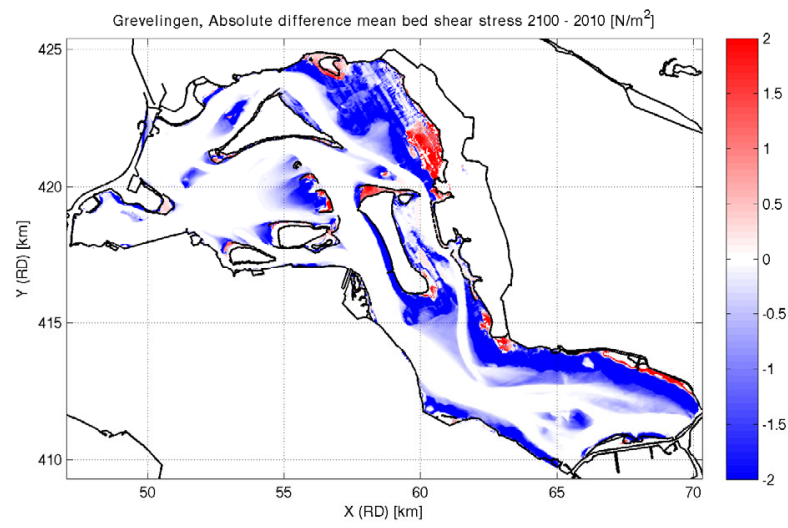

Figure 3. Difference in significant bed shear stress (2100 - 2010), daily conditions.

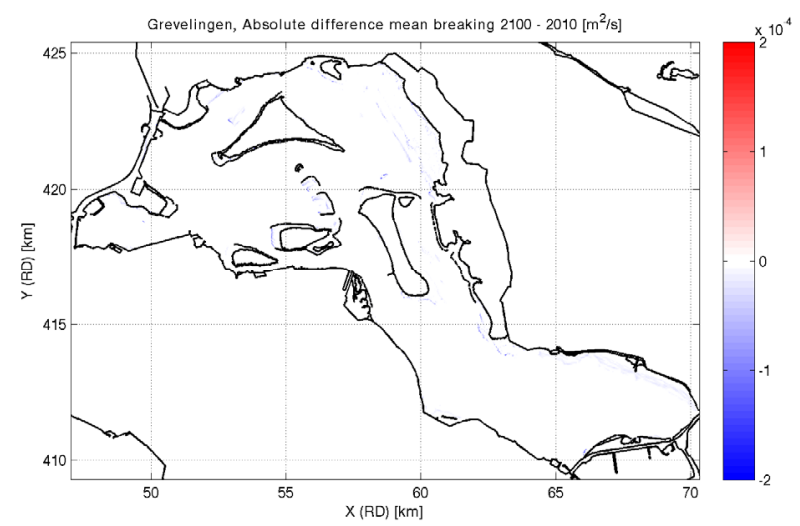

Figure 5. Difference in mean wave breaking (2100 - 2010), daily conditions. model of Lake Grevelingen. Parts below NAP $+0.1 \mathrm{~m}$ are measured recently (in 2008 and 2009). Bathymetric records of 1969 are used as a basis for bed levels above NAP $+0.1 \mathrm{~m}$, since at that time no high vegetation existed on the dry intertidal flats. More recent measurements do not give accurate information on the elevation of the intertidal flats because the data is not corrected for the presence of high vegetation.

Bank protections and foreshore defences are modelled separately (as obstacles) in SWAN and are not included in the bathymetry. The reason for this is, that these dams are small in relation to the grid size and reflection and transmission are modelled separately in SWAN. The foreshore dams are modelled with a height of NAP $+0.0 \mathrm{~m}$, a crest width of $4.0 \mathrm{~m}$ and a slope of 18.0 degrees. This results in a reflection coefficient of 0.3 . Transmission has been modelled with the formulation of d'Angremond and Van der Meer [d'Angremond et al., 1996].

The SWAN simulations are performed with the same physical and numerical settings as used for the Strength and Loading of Flood Defences Programme (SBW), as well as for the normative set of tools for the national assessment of flood defences (WTI) in The Netherlands.

\section{Boundary conditions}

To determine the change in wave conditions in Lake

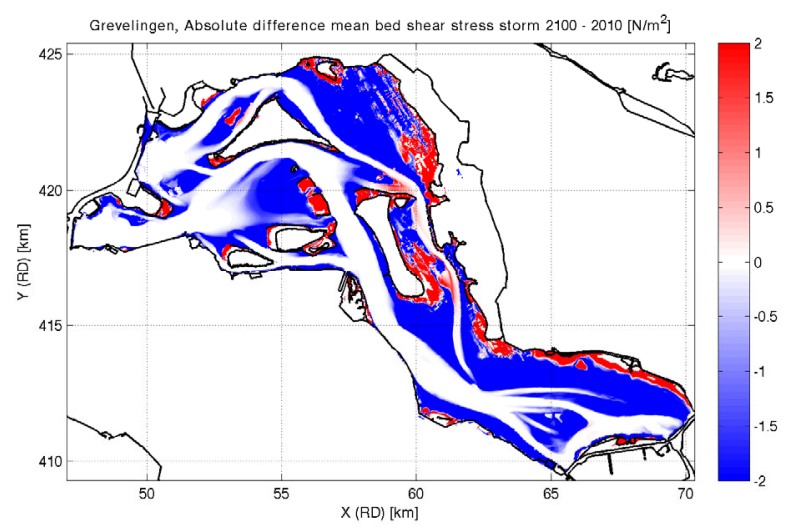

Figure 4. Difference in significant bed shear stress (2100 - 2010), storm conditions.

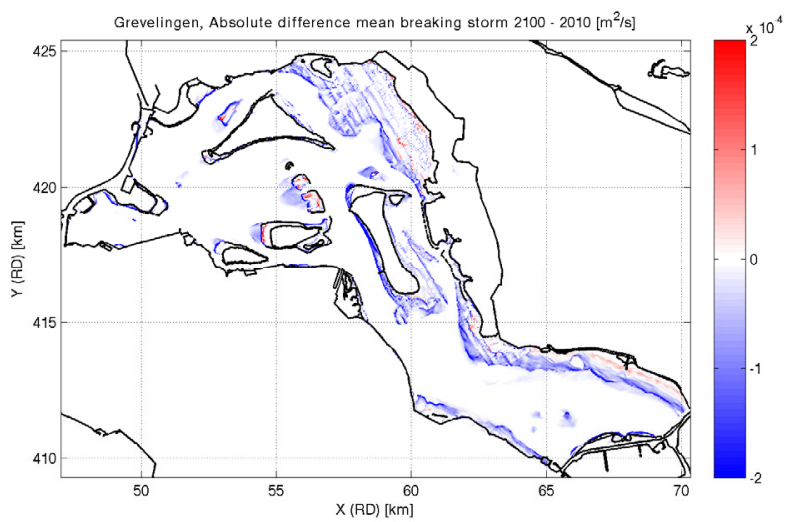

Figure 6. Difference in mean wave breaking (2100 - 2010), storm conditions. 
Grevelingen, a set of stationary SWAN computations has been carried out. The individual simulations are made for a set of conditions each with a uniform water level, a uniform wind speed and a uniform wind direction.

The stagnant water level in the present situation is NAP $-0.2 \mathrm{~m}$. Mean conditions are used such that the future situation can be compared with the present situation. The future mean conditions are composed of a combination of three water levels, i.e. the sum of: $1 / 4$ of the low water level, $1 / 4$ of the high water level and $1 / 2$ of the mean water level. The mean water level in Lake Grevelingen in 2100 is assumed to be NAP $+0.75 \mathrm{~m}$, the high water level NAP $+1.0 \mathrm{~m}$ and the low water level NAP $+0.5 \mathrm{~m}$.

The wind speeds are based on wind statistics of KNMI measurement station Lichteiland Goeree for a period of 30 years (1981-2010). The wave conditions are determined for two different wind speeds: one which is not exceeded $50 \%$ of the time (average daily conditions) and another for wind speeds that will not be exceeded $99 \%$ of the time (yearly maximum storm conditions). These input conditions are summarized in Table 1.

\section{RESULTS}

For Lake Grevelingen the situation in 2100 (with tide and with a mean water level of NAP $+0.75 \mathrm{~m}$ ) is computed and compared with the present situation (stagnant water level) by interpolating the stationary SWAN results over all wind directions.

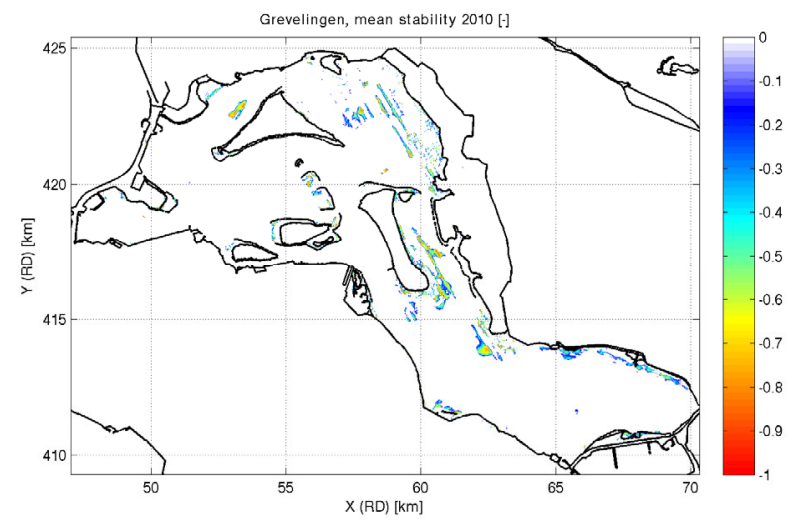

Figure 7. Mean stability of sediment in 2010, daily conditions.

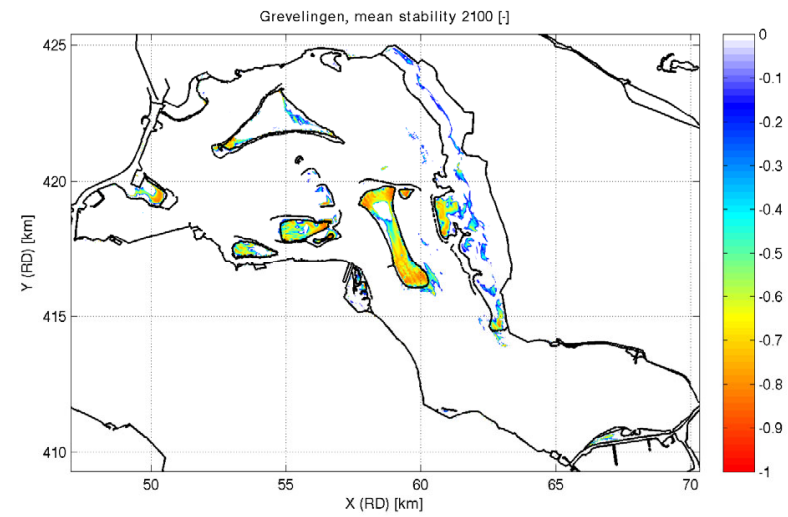

Figure 9. Mean stability of sediment in 2100, daily conditions.
Table 1: Applied wind directions and wind speeds.

\begin{tabular}{cccc}
\hline $\begin{array}{c}\text { wind direction } \\
\left({ }^{\circ} \mathrm{N}\right)\end{array}$ & $\begin{array}{c}\text { avg. wind } \\
\text { speed }(\mathrm{m} / \mathrm{s})\end{array}$ & $\begin{array}{c}99 \% \text { wind } \\
\text { speed }(\mathrm{m} / \mathrm{s})\end{array}$ & $\begin{array}{c}\text { frequency of } \\
\text { occurrence }(\%)\end{array}$ \\
\hline 30 & & & \\
60 & 7.7 & 15.8 & $8.2 \%$ \\
90 & 7.2 & 15.9 & $7.0 \%$ \\
120 & 6.6 & 14.4 & $6.1 \%$ \\
150 & 6.6 & 14.0 & $5.3 \%$ \\
180 & 6.6 & 14.1 & $5.3 \%$ \\
210 & 8.0 & 17.3 & $8.3 \%$ \\
240 & 9.8 & 18.7 & $12.9 \%$ \\
270 & 10.0 & 19.4 & $15.9 \%$ \\
300 & 8.9 & 19.6 & $9.8 \%$ \\
330 & 8.4 & 19.5 & $7.4 \%$ \\
360 & 7.9 & 18.4 & $6.5 \%$ \\
\hline
\end{tabular}

\section{Significant bed shear stress}

The differences in significant bed shear stress in Lake Grevelingen between the situation in 2100 and the present situation are shown in Figure 3 and Figure 4. It appears that the orbital velocity and therefore the bed shear stresses will decrease (due to the higher water level).

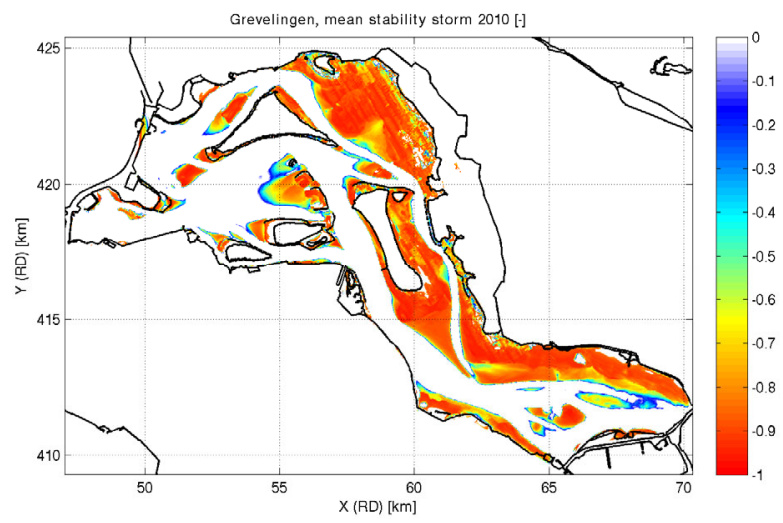

Figure 8. Mean stability of sediment in 2010, storm conditions.

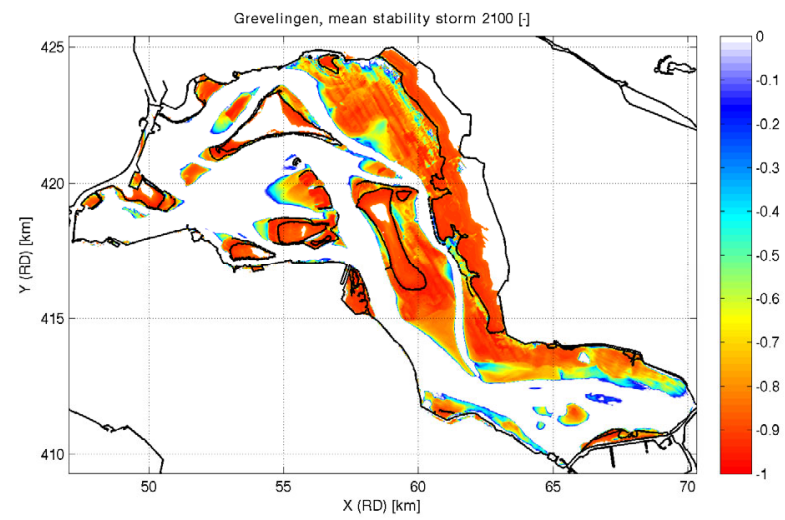

Figure 10. Mean stability of sediment in 2100, storm conditions. 
Table 2: Change of parameters in 2100 behind foreshore dams relative to the reference year 2010.

\begin{tabular}{ccc}
\hline & avg. wind & storm \\
\hline & & \\
rel. difference significant wave height & $+107 \%$ & $+97 \%$ \\
rel. difference bed shear stress & $-33 \%$ & $-32 \%$ \\
\hline
\end{tabular}

In shallow areas of the Grevelingen, the increase of the water level has a much larger influence on the bed shear stress than the increase in wave height. Only in very shallow areas (less than some decimetres), the bed shear stress will increase. This occurs under daily conditions during storm conditions.

Behind the foreshore dams, the wave heights increase and the bed shear stresses decrease in future situations (Table 2).

\section{Wave breaking parameter}

Wave breaking will decrease near the channel bank zones (Figure 5 and Figure 6). Therefore, less energy becomes available for sediment transport. A small increase of wave breaking will occur in higher parts in Lake Grevelingen in 2100. Wave breaking will move to higher located parts of Lake Grevelingen.

\section{Initial sediment stability parameter}

Figures 7, 8, 9 and 10 show the initial stability of sediment in the present situation and in 2100. A negative value means that sediment can start to move. Locations with positive values (stable) are indicated with a white colour.

Based on initial stability of sediment, it can be concluded that all low-lying areas will become more stable in the future, but that some higher parts may start eroding. The future higher water levels will cause drowning of parts of the tidal flats. And erosion may take place at these locations in future.

\section{DISCUSSION}

The combination of wave modelling and post-processing is a good method to quickly assess the risks of erosion of channel banks and tidal flats, in tidal basins. It is a simple analysis relative to full morphodynamic modelling, because of the dedicated combination of a small number of stationary simulations. This type of analysis shall off-course not be a replacement for monitoring programs. However, it can be used to get insight in the - spatial and temporal - patterns in the occurring physical processes.

Bed shear stress is a useful indicator of the influence of waves on the bed. However, an increase in bed shear stress does not necessarily mean that sediment transport will occur. Since the bed shear may be too low to initiate sediment motion.

The wave breaking parameter shows where wave breaking will occur and where waves will dissipate energy. This energy can cause sediment transport. However, wave breaking will not directly give insight in the risks of (bank / tidal flat) erosion either.

An efficient way to assess bank erosion in tidal basins is by means of the initial sediment stability parameter, because it includes both hydraulic loads on a bank and the strength of the bank. This has been presented for the case of reintroducing a tide in Lake Grevelingen.
The initial sediment stability parameter will not give the magnitude of sediment transport or the amount of erosion. However, this parameter can indicate at which locations erosion may occur in future.

Predicting bank erosion through evaluation of the initial sediment stability parameter is a conservative approach, because it is assumed that erosion may occur where grain stability is low.

\section{ACKNOWLEDGEMENT}

The presented work is part of a study commissioned by both Natuur- en Recreatieschap De Grevelingen and Rijkswaterstaat Zeeland, The Netherlands. The valuable contributions of Romke Bijker (ACRB) and Z.B. Wang (Deltares) are greatly appreciated.

\section{REFERENCES}

D'Angremond, K., J.W. van der Meer and R.J. de Jong (1996), Wave transmission at low-crested structures, ASCE Proc. ICCE, 1996.

Delft University of Technology (2011), SWAN scientific and technical documentation SWAN cycle III version 4.85, Delft.

Deltares (2010), Morfologische effecten getijdencentrale in de Brouwersdam. accompanied by 'MIRT Verkenning Grevelingen', draft version.

Deltares (2011), Delft3D-Flow user manual HydroMorphodynamics, Delft.

Kleinhans, M.G., W.M. van Dijk, W.I. van de Lageweg, R. Hoendervoogt, H. Markies and F. Schuurman (2010), From nature to lab: scaling self-formed meandering and braided rivers. River Flow 2010.

Nieuwenhuize, J., P.M.J. Herman en R.H.D. Lambeck (1995), De bodemsamenstelling van 36 meetpunten in het Grevelingenmeer in 1995 en een analyse van lange-termijnontwikkelingen (19671995).

Rijkswaterstaat Zeeland (2010), Invloed getij op oevers Grevelingen Meer.

Schiereck, G.J. and H.L. Fontijn (1996), Pipeline protection in the surf zone, $25^{\text {th }}$ ICCE, Orlando, ASCE, New York.

Shields, A. (1936), Anwendung der Ähnlichkeitsmechanik und der Turbulenz Forschung auf die Geschiebebewegung Mitt. der Preuss. Versuchsamt. für Wasserbau un Schiffbau, Heft 26, Berlin, Deutschland.

Soulsby, R.L., L. Hamm, G. Klopman, D. Myrhaug, R.R. Simons, and G.P. Thomas (1993), Wave-current interaction within and outside the bottom boundary layer, Coastal Engineering, 21 (1993), 41 - 69, Amsterdam.

Thoma, D.P., S.C. Gupta, M.E. Bauer and C.E. Kirchoff (2005), Airborne laser scanning for riverbank erosion assessment. Remote Sensing of Environment 95 (2005) 493 - 501, doi:10.1016/j.rse.2005.01.012.

Thorne, C.R. (1981), Fields measurements of rates of bank erosion and bank material strength. Proc. of the Florence Symposium, June 1981, IAHS publ. no. 133.

Van Vledder, G. Ph., J. Groeneweg, A. van der Westhuysen (2008), Numerical and physical aspects of wave modelling in a tidal inlet, Coastal Engineering 2008, 424 - 436.

Witteveen+Bos (2011), MIRT-verkenning Grevelingen milieueffectrapport, in cooperation with 'Natuur en Recreatieschap De Grevelingen'. 